January 1993

\title{
A New Voice on Personality Disorders
}

Dan Block, M.D.

Thomas Jefferson University

Follow this and additional works at: https://jdc.jefferson.edu/jeffjpsychiatry

Part of the Psychiatry Commons

Let us know how access to this document benefits you

\section{Recommended Citation}

Block, M.D., Dan (1993) "A New Voice on Personality Disorders," Jefferson Journal of Psychiatry. Vol. 11 : Iss. 1 , Article 16.

DOI: https://doi.org/10.29046/JJP.011.1.008

Available at: https://jdc.jefferson.edu/jeffjpsychiatry/vol11/iss1/16

This Article is brought to you for free and open access by the Jefferson Digital Commons. The Jefferson Digital Commons is a service of Thomas Jefferson University's Center for Teaching and Learning (CTL). The Commons is a showcase for Jefferson books and journals, peer-reviewed scholarly publications, unique historical collections from the University archives, and teaching tools. The Jefferson Digital Commons allows researchers and interested readers anywhere in the world to learn about and keep up to date with Jefferson scholarship. This article has been accepted for inclusion in Jefferson Journal of Psychiatry by an authorized administrator of the Jefferson Digital Commons. For more information, please contact: JeffersonDigitalCommons@jefferson.edu. 


\title{
A New Voice on Personality Disorders
}

\author{
BROKEN STRUCTURES: SEVERE PERSONALITY DISORDERS \\ AND THEIR TREATMENT \\ Salman Akhtar, M.D. \\ Jason Aronson, Inc., 1991
}

\section{Dan Block, M.D.}

Having benefitted from Salman Akhtar's PGY-3 course on severe personality disorders, I had the chance to preview some of the material in his book. It was with eager anticipation that I bought and read his book. After a foreward by Otto Kernberg, M.D., Dr. Akhtar divides his book into four sections: 1) identity; 2) personality disorders; 3) psychotherapy; and 4) a summary section with recommendations for treatment.

His text interweaves a rich review of descriptive psychiatry and psychoanalytic theory, from which he provides a comprehensive synthesis to describe each of the eight severe personality disorders. He does this using both an excellent command of psychiatric literature, other literature, poetry, and his own clinical experience. My experience of the book was deepened by having heard Dr. Akhtar lecture: while reading the book I could almost hear his voice explaining his ideas. However the book stands well on its own and no reader needs the experience of Dr. Akhtar's class to benefit from his ideas.

The opening section on identity has two parts, a review of analytic ideas and a description of the syndrome of identity diffusion. The syndrome of identity diffusion involves the following phenomena: 1) contradictory character traits; 2) temporal discontinuity of the self; 3) lack of authenticity; 4) subtle body image disturbances; 5) feelings of emptiness; 6) gender dysphoria; and 7) inordinate ethnic and moral relativism. His discussion of differential diagnosis of various patients brings to clinical life his description of the syndrome.

The next section addresses the eight severe personality disorders: narcissistic, borderline, schizoid, paranoid, hypomanic, antisocial, schizotypal, and histrionic. $\mathrm{He}$ combines the last two into one chapter because of a paucity of literature concerning them. Dr. Akhtar develops in chart form the notion of covert and overt features of each of these disorders, and cautions the reader not to confuse covert and overt with unconscious and conscious. While the charts are useful theoretical devices, they do not address the frequent overlap of such features in the clinical presentation, or the changing nature of the manifestations of these features over time, although he does discuss these in the text. Dr. Akhtar's command of the literature shines brightly in 
this section, though at times there is too much reliance on Dr. Kernberg's formulations.

Clinically, the most useful section of the text is the next section, which addresses the evaluation and treatment of individuals who suffer from these personality disorders. It is here that an understanding of the syndrome of identity diffusion and the concept of borderline organization are crucial. Dr. Akhtar's various recommendations on appropriateness for psychotherapy, the type of psychotherapy to use, when to consider medication, and when to hospitalize are particularly helpful to all clinicians, but especially to beginning psychiatrists. He provides a thorough discussion of the various meanings of suicide as a technical challenge for the therapist. He also provides advice on how to handle transference as well as different views on how the therapist's own personality is important. It would be enjoyable to read more of Dr. Akhtar's own clinical vignettes in this section.

The final section is essentially a summary. He concludes with "The Parable of Two Vases," a story he relates from his own experience teaching residents. In it he talks about two vases, one unmarred and the other broken and then painstakingly and expertly pieced back together, and wiser for it. Having heard the story in person only served to reinforce the Zen-like quality of the story and story teller. Overall, the text provides a comprehensive, well-informed, and eminently readable understanding of the severe personality disorders and their treatment. 